\title{
Deadlocks and breakthroughs in urban renewal: a network analysis in Amsterdam
}

\author{
Marietta Haffner · Marja Elsinga
}

Received: 18 February 2009/Accepted: 18 February 2009/Published online: 14 March 2009

(C) The Author(s) 2009. This article is published with open access at Springerlink.com

\begin{abstract}
Urban renewal in the Netherlands has become a matter of 'networking'. Housing associations, Dutch social landlords, became financially independent in the 1990s and have a responsibility in urban renewal. It is a joint responsibility in which local authority, social landlord and tenants are dependent on each other. This situation is rather new and needs some getting used to, as the two case studies show. The paper concludes that taking account of the complexity of networks could improve the chances of gaining support for problem definitions and solutions. This would result in agreement about goals and win-win package deals for actors, and ultimately in 'more' progress in urban renewal.
\end{abstract}

Keywords Complex networks - Governance networks · Housing associations · Networks · The Netherlands · Urban renewal

\section{Introduction}

In the past, urban renewal was dominated by hierarchical government steering, though there were signs of network governance at the local level. Housing and urban renewal were different worlds, however, with different ways of funding until the mid-1990s. In 1995 the housing associations, which were the Dutch social landlords, became financially independent from the government (Elsinga et al. 2008) and thereby gained power in the local network. This coincided with a new national policy in urban renewal, which was launched in 1997 in a white paper that gave high priority to the restructuring of postwar neighborhoods, areas consisting of mainly affordable social rental dwellings, owned by housing associations (Tommel 1997). The housing associations got a new task and they had funds available as a result of their financial independence. Thus, housing associations have an

M. Haffner $(\bowtie) \cdot$ M. Elsinga

OTB Research Institute for Housing, Urban and Mobility Studies, Delft University of Technology, Jaffalaan 9, 2628 BX Delft, The Netherlands

e-mail: m.e.a.haffner@tudelft.nl

M. Elsinga

e-mail: m.g.elsinga@tudelft.nl 
important role to play in this regard: they need to modernize their stock, to create more social mix, to sell and demolish part of the stock, and to invest in the improvement of the surroundings. ${ }^{1}$

The joint non-hierarchical responsibility of local actors for urban renewal is currently reflected in the fact that the local actors are involved in a local urban renewal network. This situation is rather new and dynamic, which implies that actors are changing as are the rules of the game.

In due course the national ministers of housing and the Dutch parliament became worried and dissatisfied about the progress of urban renewal. This was our motivation in 2005 to look more closely at how local urban renewal partnerships work in determining performance goals.

The governance network approach seemed appropriate as a framework for our analyses; ever since the housing associations gained financial independence, they and the municipalities have had to negotiate as more or less equal partners in a governance network to restructure neighborhoods. Our research questions were as follows:

- Which original and intertwined goals (performance targets) did the actors agree upon, and are the actors satisfied with those targets?

- How do the (changing) characteristics of local urban renewal networks influence running into decision deadlocks and achieving breakthroughs while negotiating on performance targets in the network?

- What types of perception management contributed to the breakthroughs while negotiating on performance targets in the network?

Coming up with an answer to these questions involved doing two case studies in Amsterdam, interviewing the people concerned (Haffner and Elsinga 2006). The analysis of these interviews can be found in Sects. 5-8 of this paper. For further details on the results, see the end of Sect. 3. Before we get to the results of the interviews, though, we first discuss (in the next two sections) the core ideas of the network approaches that we have used as a 'network toolbox' to analyze the cooperation among actors. The subsequent section introduces the case-study methodology. The final section sets forth the conclusions.

\section{Complex governance networks}

In a recent special issue of Housing, Theory and Society, Mullins and Rhodes (2007) distinguish five approaches to studying the cooperation between organizations in networks. These approaches enable aggregate organizational behavior to be studied in networks that operate more or less horizontally rather than vertically (Koppenjan and Klijn 2004:3). One of the strands of research that Mullins and Rhodes (2007) identify is the 'governance network approach', which, given its roots, is described as a typical continental European research approach. Networks are regarded:

as a new form of governance arising in situations where there are high levels of interdependence between organizations and the state and where hierarchical forms of

\footnotetext{
${ }^{1}$ New were also the offers that partnerships of housing associations presented to society concerning the sums they planned to invest in keeping neighborhoods livable (see e.g., Aedes 2007). Meanwhile negotiations between the sector and the central government have evolved and the government has designated the 40 'worst' neighborhoods that investments of the government and social landlords should be focused on (November 2007).
} 
'command and control' are no longer the most effective methods for policy implementation.

Works using a network approach in the Dutch literature include De Bruijn and ten Heuvelhof (1991, 1999), Klijn (1996), Koppenjan and Klijn (2004) and Teisman (1998). Common to the strands of the network approach that these researchers apply is the acknowledgment of the existence of interdependence between organizations. According to Mullins and Rhodes (2007) there is also a normative strand, where horizontal steering or influencing mechanisms enable the partners in the network to agree upon performance targets and consequently make decisions. According to Koppenjan and Klijn (2004:11-12) this approach of horizontal steering and influencing arises from a school of network theory where the management of the strategic interaction processes - the 'policy game' - is the focus of interest. The policy game takes place in the network that De Bruijn and ten Heuvelhof (1999:32, translated) define as:

a dynamic totality of actors [representing organizations] that are mutually dependent, display a diversity of characteristics and possibly operate in a relatively closed mode in relation to one another.

Networks like these can be considered a typical Dutch phenomenon, befitting the culture of compromise.

\section{Toolbox of theoretical approaches}

Our research project can be positioned in the strand where actors whose influence is about equal in the network try to influence each other. We use this approach as a toolbox which provides us with tools to answer our research questions.

\subsection{Teisman's three-step model of decision-making}

As we were concerned in the first place with performance targets, we used Teisman's (1998:78) three-step model of decision-making in relation to performance measurement. The model involves the formulation of what Teisman calls common interest, the total of the evaluations of the actors about the decision-making process. One would be able to describe the process of decision-making to some degree as effective, according to Teisman, if the actors considered the results of the decision-making to be satisfactory (step 1), even if the original targets of all involved actors (step 2) have not been totally achieved. Teisman is also interested in whether the decision-making process itself contributed to enriching interaction and decisions (step 3). Thus this approach focuses on intertwining goals and creating added value or win-win situations leading to an effective decisionmaking process.

Teisman's definition of 'effective' decision-making may be one bridge too far, however. One wonders whether a network of actors should decide about the goals that are good for a neighborhood or a society. And one wonders whether this 'effective' decision-making maximizes the utility for those concerned (however, we measure utility), or whether those concerned will set a minimum own-interest level for themselves which they will be satisfied with ('satisficing' behavior; Simon 1957). Even without answering these questions and even without drawing conclusions about whether decision-making indeed has been effective, analysis based on Teisman's three-step model of decision-making is useful in the 
sense that it provides a framework for indicating whether actors' goals are intertwined and whether win-win situations are achieved in their perception.

\subsection{Characteristics of complex governance networks}

As the networks of urban renewal, and in particular the role of housing associations therein, were considered relatively new phenomena, we were also interested in using the four characteristics of complex governance networks as introduced by De Bruijn and ten Heuvelhof (1999, 1991).

The first three characteristics concerned are interdependencies between actors, a certain degree of closedness on the part of actors, and the multifaceted nature of organizations and goals. The fourth characteristic is the concept of dynamics: changes in the network (e.g., new members) or in the context of the network (e.g., policy changes). Each characteristic in a network is given and also affects the way the other ones are reflected in the network. The characteristic of interdependencies would seem to be crucial, however, as the definition of a network mentioned above shows: if an actor is not dependent on another actor, the former will be able to operate independently without participating in a complex network.

The assumption is that the way actors deal with one another is affected by the characteristics of the complex network that they are operating in. In a situation where there is a breakthrough, we expect the network to be characterized differently than in a situation where there is stagnation or deadlock. In the former instance, the actors will be open to each other and there will be some agreement (less multifacetedness). In the latter instance, the actors will be adopting a closed attitude to each other's arguments, resulting in no agreement. Stated more generally, because actors face interdependence in the network, they will try to change the characteristics in the network in their favor in order to be able to achieve a breakthrough.

\subsection{Deadlocks and breakthroughs}

The concepts of stagnation and breakthrough arose from the interviews. They formed the terminology that the respondents used. From a more theoretical perspective, Termeer and Koppenjan (1997:79) use the term fixations with regard to interaction processes when actors are unable or unwilling to reflect on their perceptions. This will lead to stagnation or deadlock in the decision-making process. These fixations may come about as a result of different perceptions about the policy concept (cognitive variation) or different ways of acting (social variation; p. 84). Termeer and Koppenjan (1997:82) define perception as "an image through which the complex, ambiguous world which surrounds actors can be made sense of and be acted upon."

Direct and indirect strategies can be used to manage the perceptions of actors. The first group of strategies is aimed at the cognitive dimension of the interaction process: furthering a common language, preventing the exclusion of ideas, introducing new ideas and furthering reflection. The second group of strategies is aimed at the social dimension of interaction: developing new procedures, preventing the exclusion of actors from the network and introducing new actors into the network.

Termeer and Koppenjan (1997) contend that if the stagnation is the result of social factors, cognitive redefinition, i.e., a different definition of the problem, may be a strategy to follow in order to achieve a breakthrough. In the case of a cognitive fixation, a strategy directed at the process or social variation may deliver a breakthrough. 


\subsection{Our approach}

Each of the described approaches has its own merits. In order to answer our research questions, we are using these approaches as a toolbox. As indicated before, our starting point for the research project was to find out about the performance targets that had been set and to measure how satisfied actors would be using Teisman's three-step model (see the first research question). We organized the material around the following subjects:

- the original goals of the actors at the beginning of the process,

- the intertwined goals or targets that were negotiated, and

- the satisfaction of the actors with the outcomes.

We indicate how the actors viewed the joint performance targets that had been achieved and whether the decision-making in this sense can be characterized as effective. In fact, we are mostly describing steps 1 and 2 of Teisman's three-step model. And we are substituting most of step 3, except for the content aspect on goal intertwinement, by organizing the description of the decision-making process with the aid of the other approaches described. We use the (changing) characteristics of complex networks, the deadlock or delay versus breakthrough distinction in combination with the strategies aimed at perception ${ }^{2}$ management in order to formulate answers to our second and third research questions.

The analyses in Sects. 5-8 (after the description of the case-study methodology in Sect. 4) run chronologically from 1996 on. Section 5 starts with the original aims of the actors and then describes the characteristics of the network that have led to deadlock. Section 6 starts with a description of the strategies of perception management also having effects on network characteristics and in the end leading to a breakthrough. Section 7 starts with the original goals of the second social landlord, which entered the network when taking over one of the 'cases'. This section describes the strategies of perception management that led to changes in the network characteristics, adding up to a breakthrough in the end. In Sect. 8 the satisfaction of the actors with the agreed upon performance targets is analyzed.

\section{Case-study methodology}

The study involved carrying out two case studies in Amsterdam, whereby the 21 persons concerned were interviewed from mid-December 2005 to mid-March 2006. We searched for individuals who had been intimately involved in the process for some length of time: tenants' associations (three persons), politicians (two persons), civil servants at the district council (4), employees of the social landlords (7), and others who were involved, such as external project managers (1), independent chairpersons (2), architects (1) and tenants' representatives (1).

The interviewees were asked to tell in which part of the process they had been participating in the network. In the semi-structured interviews, they were furthermore prompted to explain how they perceived the collaboration, the interdependencies and the influencing/steering activities in the network. Last but not least, the interviewees were asked about their original targets, the targets that were negotiated and their satisfaction with the outcome in the end.

The reconstruction of the collaboration process in the case studies by the research team is based on the interviewees' perceptions. Also, 'the' compromise document was available,

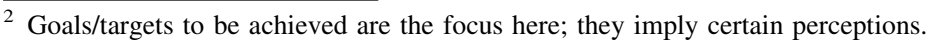


as was an archive of one of the social landlords. The archive contained many relevant documents, such as minutes of meetings. As different documents or interviewees often described the same situation, the problem of faulty recollection was prevented as much as possible.

A general problem with interviewing (partly) after the decision-making had largely been completed become even more pronounced when using the approach of Teisman: people may be biased, more positive or satisfied than otherwise because they had been part of the decision-making process. It may also be the case that actors in the network who judge their own work are probably inclined to be (too) positive about their own efforts and contribution to the results. This is also a question of to what extent actors will try to justify decisions after the event (the theory of cognitive dissonance reduction; see Kotler 1980). With some precautions, checks and balances were built into the reconstruction process in order to minimize the biases. This entailed following the process from the original goals through to the setting of performance targets and then interviewing, when possible, several informants for each actor involved.

The interviewees were given the chance to comment on the report; this was a means to check the reconstruction of the collaboration process. Their comments were then incorporated. Such an exercise, especially one where everyone believes their own truths (even the researcher), is of course a tricky one. Thus, when different opinions were detected, the discrepancies were mentioned in the report. But the general opinion was that the report presented an acceptable reconstruction of the collaboration in these two case studies.

\section{Reaching deadlock}

The garden village of Tuindorp Oostzaan (TOZ) and two other garden villages, namely Disteldorp (226 dwellings) and Vogeldorp (315 dwellings), were involved. The latter two villages form a single case study, as they were treated jointly in the decision-making process up to the moment when the planning of the renovation process started. These two villages are lumped together here in one case study, while part of Tuindorp Oostzaan has been left out of the picture. A little more than half of TOZ, which contained 1,340 dwellings, forms the second case study, which covers the neighborhoods called Mercuriusbuurt, with 315 dwellings, and De Ring, with 499 dwellings.

The history of these garden villages started early in the last century when they were built in the north of Amsterdam. Disteldorp and Vogeldorp were built in 1918/1919, TOZ in the period 1919-1923. The mostly social rented, small row houses were built for the working class. They were meant as semi-temporary dwellings with an expected lifespan of 10 years in Disteldorp and Vogeldorp and 35 years at most in TOZ. Somehow the dwellings were renewed regularly and in the early 1980s they were renovated one more time, supposedly for the last time. By the 1990s they were considered very small, poorquality dwellings with a very low rent.

As the three villages are not adjacent to one another, and as the expected lifespan of their respective dwellings differed, the maintenance and restructuring processes of TOZ on the one hand and of Disteldorp/Vogeldorp on the other went through separate trajectories for most of the twentieth century. This also happened with the renovation process itself. Renovation was finished in 2001 for TOZ and in 2003 (dwellings) and 2006 (outdoor space) for Disteldorp and Vogeldorp. That is why the three villages are treated as two case studies. 
For TOZ the last round of the restructuring process started in 1989 when Woningbedrijf Amsterdam (abbreviated WBA) put forward demolition plans for TOZ. The negotiations led to the decision to split up the renovation plans for TOZ into four phases. Phase 1 and 2 were realized in the early to mid-1990s with the help of the then-still-available national bricks-and-mortar subsidies.

When no more bricks-and-mortar subsidies were available after the financial independence of the housing associations, new plans had to be made for phase 3 (Mercuriusbuurt) and phase 4 (De Ring). The period of analysis of the two case studies was set to start in 1996, when WBA put forward the improvement scenarios for these two phases.

\subsection{Original performance targets}

In 1995, no more national bricks-and-mortar subsidies were to be pumped into future improvements of housing. At that time, WBA set out a strategy to improve the quality of the dwellings in its portfolio, too many of which it considered small, low-rent and of poor quality. To achieve a healthy portfolio strategy, future maintenance risks had to be reduced and the housing stock had to become more differentiated (see Table 1).

The improvement scenarios that WBA put forward in 1996 for phase 3 (Mercuriusbuurt) and phase 4 (De Ring) of TOZ included high-level renovation and enlargement of dwellings. These plans would allow higher rents to be charged than tenants could pay. Thus they allowed only for a maximum of one in three households to return to TOZ after the intervention (Woningbedrijf Amsterdam 1996; Bureau P/A 1997). The scenario that allowed about $90 \%$ of tenants to return after the intervention was considered financially

Table 1 Original targets of actors regarding Mercuriusbuurt/De Ring and Disteldorp/Vogeldorp

\begin{tabular}{ll}
\hline Actor & Targets \\
\hline Social landlord WBA & Upgrading of the quality of the dwelling portfolio \\
& Creating good future values \\
& Creating neighborhoods with a differentiated dwelling stock \\
& Doing a low-level renovation will not do in light of the above; maintenance \\
& risk remains too high \\
& Preserving of the villages \\
Tenants' associations of & Being able to return after renovation \\
garden villages & Renovating at low level \\
& No selling of dwellings \\
& No combining of dwellings into bigger ones \\
& Keeping rents affordable \\
& Agreeing initially with plans of WBA \\
& Later: changing relatively quickly to support to tenants because a housing \\
& segment could be saved for Amsterdam, an iron stock of affordable \\
housing & Creating differentiation of life styles within villages \\
District council & Maintaining as much social cohesion as possible \\
& No selling of dwellings in the allocation system (affordable housing) \\
& Saving cultural and historic value of villages
\end{tabular}

\footnotetext{
a In 1993 the municipal housing company changed its legal status to that of a housing association

b These were the aims pursued by the tenant organizations. Tenants have multifaceted goals, however. This may be illustrated by the $26 \%$ of tenants in Disteldorp who would have preferred new construction versus $13 \%$ in Vogeldorp, $10 \%$ in De Ring and 7\% in de Mercuriusbuurt (unpublished housing preferences survey in the three villages that was commissioned by the Negotiation Team)
} 
unfeasible. As the tenants did not want to leave their villages (see Table 1 for list of their targets), they protested. A serious deadlock came about in the decision-making network for Mercuriusbuurt/De Ring. It was called a 'hotbed' in the interviews.

The tenants' associations of Disteldorp and Vogeldorp were closely following the discussions around the renovation of Mercuriusbuurt and De Ring. Trying to avert the fate of having to leave their village, Vogeldorp had organized the celebration of its 75th anniversary in 1993 to attract publicity. It also offered its own renovation plans based on a tenant survey. However, these activities did not prevent WBA and the tenants' organizations of Disteldorp and Vogeldorp from reaching deadlock.

In the beginning the district council of Amsterdam North was not a party in any of the negotiations, because social landlords had just become financially independent from the government. There was no direct role for the district council in this decision-making process. But as soon as the tenants started seeking publicity and approaching politicians, the district council became involved. After some initial doubts, the district council became convinced that the garden villages could fulfill a new function on the Amsterdam housing market (see goals in Table 1). In that light, it supported the residents and decided that it would not issue the necessary permits for the plans of WBA. Some interviewees posited that the district council changed its position because of the negative publicity and the threat of having to relocate the many low-income households.

\subsection{Characteristics of complex network set for deadlock}

All characteristics of complex networks appeared to have contributed to the cognitive impasse in the negotiations, as Table 2 shows. Changed housing policy contributed, in the first place, in that supply-side subsidies for housing were abolished. This meant that housing associations would have to make unprofitable investments when building or renovating affordable dwellings. The impasse was aggravated by the fact that it had not yet become accepted policy to sell homes in order to fund investments. Social landlords had not yet become used to their new financial freedom and had not yet adjusted their portfolio strategy.

Furthermore, WBA and the tenants not only had multifaceted perceptions, they also seemed to speak different languages, as they were not understanding each other's arguments (social variation). The solutions put forward by WBA were portfolio-driven and had to be financially self-supporting, as government grants were no longer available for the

Table 2 Characteristics of complex networks explaining the deadlock

\begin{tabular}{ll}
\hline Characteristic & Result \\
\hline Dynamics & $\begin{array}{l}\text { Renovation subsidies no longer available } \\
\text { Sales of social rental dwellings unusual } \\
\text { Early switch of local council to supporting tenants } \\
\text { Multifaceted nature } \\
\text { of goals }\end{array} \quad \begin{array}{l}\text { Social landlord wanted to improve portfolio } \\
\text { Residents wanted to stay in their affordable homes in their neighborhoods } \\
\text { It rained reports and scenarios } \\
\text { Social landlord and tenants did not open up to each other's arguments; } \\
\text { autual dependence }\end{array} \quad \begin{array}{l}\text { Local council did not want to lose political support } \\
\text { Local council did not issue permits }\end{array}$ \\
& Local council depended on social landlords for investment \\
\hline
\end{tabular}


operation. The primary concern of the residents, on the other hand, was the social cohesion of the neighborhood, the possibility of returning to their villages and remaining in affordable housing. The result was cognitive deadlock, as WBA and the tenants' organizations were not prepared to compromise. Instead, every actor produced their own reports in an attempt to prove how the expert reports and/or scenarios of the other actor were wrong. "It really was one expert versus another, and if you had brought in another consultant, then the problem would not have changed." 3

Yet another factor that produced the impasse was the considerable degree of interdependence between WBA and the district council. The local council was dependent on the social landlord for investment, while the social landlord was dependent on the local council for issuance of permits to combine and enlarge dwellings.

It can thus be posed that all characteristics of a complex network contributed to the impasse in the collaboration process in the two networks. In our case studies, the interdependence of the partners in the network, especially between the social landlord and the district council, resulted in deadlock. The regulation stipulating that tenants need to be consulted (but not necessarily listened to) gave the tenants the opportunity to stay in the network and play an important role.

\section{Achieving a breakthrough}

In terms of perception management, one important direct strategy and one crucial indirect strategy were combined to make a breakthrough. The indirect strategy for variation in the social fixation turned out to be the initiative of the district council to set up the Garden Villages Negotiation Team in 1997. The agreement on the way forward was also ascribed to actions of tenants to involve the media and politicians in the process. The strategy for breaking through the social fixation (not speaking the same language) was a redefinition of 'the' problem. Instead of treating the two case studies separately, the negotiations were to be concerned with all of the villages at the same time.

Two independent chairpersons headed the Negotiation Team, with the district council, WBA and the three residents' committees of the three villages participating. Setting up the Negotiation Team allowed for the entry of new actors with fresh ideas, new procedures and the rearrangement of interdependencies. These strategies are elaborated on below from the viewpoint of network characteristics.

\subsection{Breakthrough in terms of network characteristics}

The proposal of the district council to set up the Garden Village Negotiation Team supported the multifaceted nature of goals and actors, as Table 3 shows, by allowing new actors to enter the network. First, there was the Negotiation Team itself, led by its two independent chairpersons. The chairpersons ensured that the interdependencies between the actors were rearranged by setting preconditions for the negotiations. All parties had to be willing to compromise and to take one another's interests and perspectives into account. The actors said that they regarded staying in an impasse as unacceptable because of the poor quality of the dwellings (change in perception).

\footnotetext{
3 This was mentioned in the interviews. An example for Disteldorp/Vogeldorp was the expert report that the tenant associations had commissioned as a response to the 1996 proposals of WBA.
} 
Table 3 Characteristics of complex networks explaining the breakthrough

\begin{tabular}{|c|c|}
\hline Characteristic & Result \\
\hline $\begin{array}{l}\text { Multifaceted nature } \\
\text { of network }\end{array}$ & $\begin{array}{l}\text { Combining the negotiation of the two cases } \\
\text { Entering of new actors in network: chairpersons of and Garden Village } \\
\text { Negotiation Team } \\
\text { Entering of other new actors in network (e.g., technical advisers) }\end{array}$ \\
\hline Mutual dependence & $\begin{array}{l}\text { Rearrangement of mutual dependence by having actors promise to find a solution } \\
\text { Negotiation of extra subsidy from the city of Amsterdam by district council for } \\
\text { Mercuriusbuurt/De Ring }\end{array}$ \\
\hline Closedness & $\begin{array}{l}\text { Openness was forced by agreeing on setting up of a Garden Village Negotiation } \\
\text { Team } \\
\text { Openness was forced by having actors promise to compromise } \\
\text { Openness was created by putting effort into making actors understand the } \\
\text { standpoints of other actors } \\
\text { Openness was created by the input of new technical advice (new technical solution } \\
\text { for damp problem) }\end{array}$ \\
\hline Dynamics & $\begin{array}{l}\text { Unprofitable investment by social landlord became usual } \\
\text { Sale of rental dwellings became acceptable } \\
\text { Different approaches for different villages } \\
\text { Point of no return }\end{array}$ \\
\hline
\end{tabular}

The entry of new actors also allowed a new exchange of ideas. Fresh ideas came in and were given a chance. One very important new idea was to use new technology to solve the problems of damp in the dwellings. The dampness was one of the reasons why the social landlord had wanted to demolish some dwellings; the landlord did not believe that the quality of the dwellings could be brought up to modern standards. When the new technology became available, renovation became an option (forced openness). Another successful idea that improved the chances of renovation was to open up (again) negotiations with the central city of Amsterdam about a financial injection for the improvement of the two neighborhoods in TOZ.

Different mediators - the project leaders, the independent chairs of the Negotiation Team, and the officials supporting the residents-built bridges to create understanding for each other's standpoints. A good deal of attention was devoted to breaking down language barriers in order to be able to include the tenants as a relevant actor in the network. ${ }^{4}$

Changes in the policy frameworks furthermore created opportunities for social landlords. The sale of social rented homes turned from a taboo into a generally accepted policy. It enabled social landlords to sell more homes and generate revenue in order to reduce or eliminate the deficits resulting from improvement schemes. Investing at a loss in social rental housing became more common too, as housing associations came to be regarded as a revolving fund. This was possible when financial independence became reality as a result of having received all future subsidies at once in 1995.

Another important aspect of the dynamics in the process was reaching the point of no return. The Garden Villages Negotiation Team was supposed to come up with a compromise. Thus the sale of Disteldorp/Vogeldorp 'had to pop up' as a solution, as long as WBA did not accept the idea of a low-level renovation for these garden villages. Regarding TOZ, two interviewees said that the whole intermezzo of the Negotiation Team would not

\footnotetext{
4 The chairpersons related that they put effort into making tenants understand the position of the social landlord. WBA contended that the chairpersons were perceived to be too much on the side of the tenants.
} 
have been necessary. Because of good relations in the past between WBA and the tenants, and because of a good project manager, the stagnation would have been overcome anyway.

However, the dominant opinion was that the intervention by the Negotiation Team Garden Cities led to a change in the network characteristics. This change was necessary to allow for a breakthrough. Reaching a compromise against all odds meant breaking through the animosity that surrounded the negotiations.

\subsection{Common performance targets achieved}

Because of combining the negotiations about the three garden villages in the Garden Villages Negotiation Team, the package of possible trade-offs became bigger than each of the separate negotiations per case study. A new exchange of ideas thus became possible; the feasibility of package deals, creating win-win situations for all actors, increased.

The compromise consisted of the following points:

- preservation of the villages (residents' and district council's target)

- joining of dwellings in all villages except for Mercuriusbuurt (differentiation of housing stock; WBA's and district council's target)

- sale of Disteldorp/Vogeldorp to a new owner (WBA's target) that would renovate them according to the requirements laid down in the compromise (residents' target)

- low-level renovation of Disteldorp/Vogeldorp (residents' target)

- high-level renovation of De Ring (WBA's target)

- low-level renovation of Mercuriusbuurt (residents' target)

- guarantee that all tenants who wished to return would be able to return after renovation (residents' target)

- limit on rent levels for tenants returning after the renovation (residents' target)

- sale of $10 \%$ of the dwellings as owner-occupied homes (WBA would have liked to sell more in order to fund the improvement scheme, the tenants fewer)

- cooperation between actors in making an improvement plan for the refurbishment of the outdoor space (WBA's and residents' target).

On finance, the deal consisted of:

- construction by WBA of 600 new social rented homes elsewhere (WBA's target)

- subsidization of part of the renovation in De Ring and the Mercuriusbuurt by the city of Amsterdam (WBA's target)

- investment at a loss to WBA in order to produce enough future value of dwellings (norm amount offered by WBA).

Together the agreement boiled down to a flexible treatment of renovation in the three garden villages and a guarantee that after renovation the tenants would be able to return at a certain rent level. The strategy of redefining 'the' problem-putting the two cases into one basket-which was aimed at breaking through the social fixation of not speaking the same language, turned out to be sufficiently flexible. It allowed all actors to reach a satisfying solution.

With the compromise of the Garden Villages Negotiation Team, not all of the decisions had been made, however, especially not for Disteldorp/Vogeldorp (case 2). For De Ring and the Mercuriusbuurt (case 1) the compromise was the starting point for the renovation process. In fact it was the continuation of the renovation process that had been taking place in other parts of Tuindorp Oostzaan in phase 1 and 2 of the intervention and that was finished in 2001. 


\section{Towards urban restructuring of Disteldorp/Vogeldorp}

The result of the compromise was the decision that WBA would try to sell Disteldorp/ Vogeldorp; in network terms, this would change the composition of the network. A buyer needed to be found, one that would agree to renovate the villages according to the compromise that had been achieved. An Amsterdam housing association, De Key, was willing to buy the two villages mainly for strategic reasons; it wanted to strengthen its position in the North of Amsterdam.

\subsection{Performance targets assigned}

Once it had been decided that De Key would do the renovation, De Key started its own process of analysis early in 1999 based on the list of goals that came out of the agreement of the Negotiation Team:

- preserving of the villages

- willing to take a loss (now De Key)

- guaranteeing the right of return for tenants after renovation

- guaranteeing affordable rents for returning tenants

- joining of dwellings (dwelling differentiation).

The decision-making process was heavily influenced by efforts, especially those of De Key, to get the district council to fulfill its promise about having the refurbishment of the outdoor space done as soon as the work on the dwellings was finished. In terms of perception management, these efforts can be characterized as trying to soften up the civil servants and politicians, each time trying a new person when others had not managed to make things happen. This was not only considered necessary on the point of outdoor space, but it was deemed crucial in order to obtain more funds. In the end, extreme measures had to be taken to force the district council to reflect further on the issue. In terms of perception management, it could be described as a 'new procedure': to stop all preparations in order to increase the pressure on the district council. The effects of these different strategies on characteristics of the network and goal intertwinement will now be described.

\subsection{Characteristics of complex network conducive to delays, but also a breakthrough}

Bringing an enthusiastic new actor into a network-in this case, De Key, who was willing to do the renovation-resulted initially in a breakthrough in the renovation process of Disteldorp/Vogeldorp. After becoming the owner of Disteldorp/Vogeldorp, however, De Key started making its own renovation plans, making its own analyses and setting its own performance targets. New negotiations had to start, causing some delay in the process. This is what Table 4 shows: bringing in De Key signified a breakthrough in the process, as the restructuring did get done in the end, but starting up a new process in a new network led to some new delays/deadlocks in the process.

One of these was that De Key aimed for a higher level of renovation than agreed upon in the compromise of the Negotiation Team; De Key wanted this in order to ensure the future value of the property. This meant that more financing needed to be arranged in due course. Also, for De Key, it was important to combine the renovation of the dwellings with the refurbishment of the outdoor space, as had apparently been agreed orally when De Key promised to take over Disteldorp and Vogeldorp. However, the district council was 
Table 4 Delays and breakthroughs in terms of characteristics of complex networks once De Key agreed to do the renovation of Disteldorp/Vogeldorp

\begin{tabular}{|c|c|c|c|}
\hline Characteristic & Result & Delay & Breakthrough \\
\hline $\begin{array}{l}\text { Multifaceted nature } \\
\text { of network }\end{array}$ & New actor: housing association De Key ${ }^{a}$ & Yes & Yes \\
\hline \multirow{2}{*}{$\begin{array}{l}\text { Multifaceted nature } \\
\text { of goals }\end{array}$} & De Key wanted a higher level of renovation & Yes & \\
\hline & De Key wanted refurbishment of outdoor space & Yes & \\
\hline \multirow[t]{3}{*}{ Mutual dependence } & Stop of renovation preparation by De Key & Yes & Yes \\
\hline & Extra subsidies for monuments, energy saving, etc. & Yes & Yes \\
\hline & $\begin{array}{l}\text { District council had to negotiate extra subsidy from } \\
\text { the city of Amsterdam }\end{array}$ & Yes & Yes \\
\hline \multirow[t]{2}{*}{ Closedness } & $\begin{array}{l}\text { Openness was forced by De Key about funding when } \\
\text { it stopped its renovation preparation }\end{array}$ & Yes & Yes \\
\hline & $\begin{array}{l}\text { Openness was forced by De Key and tenants by not } \\
\text { accepting } 2007 \text { as year of start of refurbishment of } \\
\text { outdoor area }\end{array}$ & & Yes \\
\hline \multirow[t]{5}{*}{ Dynamics } & Increase in building costs & Yes & \\
\hline & $\begin{array}{l}\text { Increase in interest for property value by the } \\
\text { independent housing associations }\end{array}$ & Yes & \\
\hline & Sale of social rental dwellings became usual & Yes & Yes \\
\hline & Point of no return & & Yes \\
\hline & Changes in employees and politicians & Yes & Yes \\
\hline
\end{tabular}

a This is the only result where the breakthrough came before the delay. In the long term the fact that De Key restructured Disteldorp/Vogeldorp must be considered a breakthrough

responsible for the investments in the outdoor space. Therefore, the value of the properties of De Key depended on the investment by the district council.

Because of these (new) performance targets, but also because of the increase in building costs, the process of renovation preparation became more complex than expected; more negotiations became necessary. The extra negotiations caused delays in the renovation process, as Table 4 shows.

At some point De Key stopped all renovation preparations. The reason was that it got insufficient cooperation from the district council on two issues: funding and refurbishment of outdoor space. Eventually funds were found little by little. These came from various subsidies: e.g., one from the city of Amsterdam and another for the monumental status of the villages. De Key used a strategy of presenting 'the problem' again and again to different politicians and civil servants (new actors), making use of the multifaceted nature of the local government.

At some point, in order to get the investment financed, De Key found itself compelled to propose the sale of at least $25 \%$ of the stock as owner-occupied dwellings, even though it earlier had announced that it did not want to sell any at all if it was not a financial necessity. The tenants had agreed to $10 \%$ in the negotiations of the Negotiation Team. Due to changes in national and local housing policy, little by little the share of the dwellings to be sold crept up to 25 , to $40 \%$ and to almost $50 \%$ in the end, because the losses started rising above the norm that De Key was prepared to accept. Higher losses were partly caused by the aim of De Key for a higher proportion of low-level renovation, desirable from a management perspective, than the agreement of the Negotiation Team called for, but also by additional stagnation in the process. Some interviewees expressed the opinion 
that losses came about because the agreement of the Negotiation Team had been hurried along too fast. Costs could not be estimated precisely enough. Also there were some skeletons in the closet.

The fact that De Key more or less unilaterally forced the (in the end) $50 \%$ sale of dwellings onto the partners in the network characterized the way De Key treated the tenants, according to some interviewees. It was less a matter of participation and offered less choice to tenants than the tenants in De Ring/Mercuriusbuurt.

On the point of refurbishment, De Key finally reached a point of no return. Further delay would result in an irresponsible rise in the costs. De Key had to start the renovation of the dwellings while a deal about the refurbishment of the outdoor space was still nowhere in sight.

The delay in the process of negotiation about the refurbishment of the outside space was due in part to a shift in the roles of local government and the housing associations as a result of the latter gaining independence. The shift meant that the associations, because of their responsibility for their portfolios, attached growing importance to having outdoor space that was in order and keeping it that way. Thus the debate on the refurbishment of the outdoor space increasingly affected the debate on how to tackle a particular neighborhood in urban renewal. The compromise that was reached by the Negotiation Team did not properly regulate who would fund the work on the outdoor space. The issue dragged on, partly as a result of changes in the political complexion of the district council and the fact that the district council had not reserved any funds for the refurbishment. The compromise reached by the Negotiation Team about the outside space was only about the process, not about who, when and how. When the district council proposed to delay the works on the outdoor space again, De Key and the tenants made a fist, successfully opposing this idea in a meeting of the district council.

The tenants complained that in the end they themselves were the only ones who knew about the agreements reached. In network terms, the other actors were closing up again. This was a result of the multifaceted nature of the organizations and of the already mentioned dynamics, notably in the change of politicians and employees at the district council and De Key.

From Table 4 one can conclude that bringing a new actor into a network, namely De Key, who was willing to do the renovation, resulted in a breakthrough at first. Once the new actor started acting in the network, it played its own role, setting its own performance targets in a changing context. New negotiations had to start. Some of these, such as the negotiations about the increase in the sale of dwellings, led initially to further delay but later to a breakthrough, which occurred when another part of the financing of the renovation could be arranged. Another example is that De Key stopped the renovation preparations in order to force the district council to come up with solutions and commitments, such as some extra funding. The further the preparations advanced, the less the option of stopping became feasible; the train had left the station. The point of no return was reached in due course, even if other actors closed up again. De Key had to start the renovation. In the end the characteristics of the complex network changed. This was necessary to get the renovation of Disteldorp/Vogeldorp under way, and also to start the refurbishment of the outdoor space.

\subsection{Intertwined goals}

It took De Key and the tenants about 2 years to formulate and agree on the joint targets:

- preservation of the villages (De Key's and the tenants' target) 
- aiming for higher low-level renovation from management perspective than in the agreement of the Negotiation Team (De Key's target)

- willing to take a loss (De Key's norm)

- selling dwellings (up to almost 50\%) because of losses bigger than the norm, but from a social point of view; homeownership for households with a lower income (De Key's target)

- guaranteeing return after renovation for tenants (based on agreement of the Negotiation Team)

- guaranteeing affordable rents for returning tenants (based on agreement of the Negotiation Team)

- carrying out refurbishment of outdoor space as soon as possible after renovation of dwellings (based on agreement between De Key and the district council)

- differentiating dwelling size (based on agreement of the Negotiation Team)

In 2001, the renovation of the dwellings could start; in September of 2003 it was finished. The refurbishment of the outdoor space took place between 2004 and 2006.

\section{Satisfaction with intertwined performance targets?}

In the process of decision-making about the interventions in the three garden cities, the performance targets were intertwined twice. The first instance was in the agreement that the Garden Villages Negotiation Team reached (Sect. 6). A win-win deal was achieved in the compromise by adopting a flexible solution, i.e., not tackling all the villages in the same way. Another important factor in achieving a compromise was overcoming the reservations that WBA had about the future value of the villages, in particular the low-level renovations that were agreed upon. Disteldorp and Vogeldorp would be sold; the future value would not be a responsibility of WBA.

The second time goals were intertwined was for Disteldorp and Vogeldorp (Sect. 7). The targets were intertwined as a result of the combination of the agreement that was reached by the Negotiation Team with those of De Key. The agreement contained the goals that the tenants brought into the negotiation with De Key, but set at the same time the starting goals for De Key. Then the targets were adjusted, mainly by De Key. This was because of the financial situation that was going against the project, but also because De Key upgraded the quality of the renovation in comparison to the agreement of the Negotiation Team more in the direction of its own standards.

Setting performance targets in networks is evidently no simple matter. Actors that have different targets need to be reconciled (multifaceted networks). One wonders whether portfolio policy should be as important as social cohesion between the tenants. In these case studies, we saw a social landlord selling off two garden villages because it believed that urban renewal involved changing the housing stock, not just renovating it. The association that bought the villages saw things differently. As one of the interviewees stated, it is indeed not simple to evaluate what happened:

For less money you could have built new dwellings. For the same amount of money you could have built more dwellings. We've saved a piece of history. We've saved a piece of social relations.

The district council, the residents and De Key are generally positive about the outcome of the cooperation process: an enhanced solution has been achieved; affordable housing in 
the rented and owner-occupied sector is available for Amsterdam; residents were able to return (70\% returned in Tuindorp Oostzaan, 50\% in Disteldorp/Vogeldorp); differentiation of the housing stock has been achieved; housing quality has improved; an ensemble of cultural heritage has been preserved; and social cohesion in the garden villages has largely been maintained.

Each actor has had to revise his initial goals to enable goal intertwinement. Those residents who have returned are now paying more than twice the amount of rent (even with housing allowance) and have problems with the large numbers of homes that have been sold. All dwellings in the Mercuriusbuurt have been sold, and in Disteldorp/Vogeldorp sales reach almost $50 \%$ of the stock.

As far as the WBA is concerned, urban renewal has not been achieved (only renovation); not enough future value has been created. Furthermore, WBA would have liked to mix rental and owner-occupied dwellings in all of Tuindorp Oostzaan, instead of selling off only the dwellings in Mercuriusbuurt (those with the lowest quality). Furthermore, one of the agreements has not been fulfilled: no contract had been realized for the construction by WBA of 600 new rented homes elsewhere by the time the interviews were held.

Even though goals were intertwined in the renovation plans for Disteldorp and Vogeldorp, presumably once De Key started its preparations, quite soon 'the moving train effect' became apparent. De Key made a commitment and tried to keep to standards for the renovation that were set as high as possible but still below its own. De Key also tried to keep its loss to a norm level that it had set at the beginning of the decision-making process. But the problem was that it had committed itself to the renovation. That work could not be postponed forever, not only from the point of view of its reputation but also in view of the costs incurred to develop the renovation plans in more detail. The train had left the station and could not be stopped anymore. This argument also explains why De Key was 'pulling at the right sleeve', when the sales of dwellings 'had to be increased' to finance the renovation. The 'moving train' created a power imbalance between De Key and the tenants. De Key was in the position to argue its standpoint and 'win'.

However, the process went, in the end De Key was still concerned about the future management of the homes in Vogeldorp and Disteldorp, as not all of the damp problems had been solved by the time the interviews were held.

Even if some the actors may not be $100 \%$ satisfied with the outcome of the cooperation process in the network for restructuring the garden villages, in general the decision-making delivered common performance targets which directed the renovation processes.

\section{Local networks in urban restructuring: a tall order}

In this study, we have used a combination of governance network approaches to describe the two case-study areas (covering three garden villages) in Amsterdam. We analyzed the setting of performance targets, the changing characteristics of networks and the managing of perceptions. And we discussed how these dimensions 'colored' the delays or deadlocks and breakthroughs in the process of 'networking'.

\subsection{Setting performance targets}

The case studies show that in a network there cannot be an a priori definition of good performance; this has to be the outcome of negotiation. Thus, doing nothing at a certain 
time may also represent good performance on the part of the actors in a network. Considering that each urban restructuring network may be unique, each network will most likely have to negotiate its own performance targets.

The negotiated performance targets were apparently win-win outcomes offering added value for or enhanced solutions to the actors. This should not come as a surprise, since even if the actors are dependent on one another, an actor will not agree to a deal that brings no advantages. A compromise would thus necessarily be inferior to some other outcome, e.g., a solution initially preferred by one or more of the partners in the network.

\subsection{Role of network characteristics}

Operating in a local network of urban restructuring involves organizing the parties in a setting where other steering tools of a more hierarchical nature are not (or not strongly) present or do not work. Actors are dependent on one another for formulating performance targets, making decisions, and then financing and implementing them. Actors will try to steer or 'seduce' other actors in the network in order to find common ground for interdependent actors. They will try to change the characteristics of the network in their favor or they will make use of changed characteristics. Adding new actors to the network or stopping the financing of the renovation are examples of the former. An example of the latter is the housing policy that changed nationally but also locally, allowing the sale of social rental dwellings.

The characteristics of the networks studied were different in a deadlock or delay situation than in a breakthrough situation. Accepting that mutual dependence of the actors within the network is the most important characteristic of decision-making in networks, 'forcing' openness of the actors towards each other appeared to be crucial. An example here was the Negotiation Team, where the interdependence relations were changed by having actors promise to understand other positions and to compromise.

\subsection{Perception management}

Performance targets imply that certain perceptions are underlying. They can be managed by process or by content. The case studies gave examples of both of these options. Stagnation on the content of perceptions was resolved by changing the process: setting up the Negotiation Team. The case studies also provided an example of changing the content-putting all villages into one negotiation basket - in order to resolve stagnation in the decision-making process.

The possibilities of the actors in the network-social landlord, district council and tenants - to influence the decision-making in the network proved to be different. Local government turned out to have the strongest role, as it was able to put its hierarchal powers to use by not granting the necessary permissions. The tenants turned out to have a mixed role. By law they have the right to be informed about important changes, but the social landlord is not obliged to follow their advice. In the case studies, the tenants who showed a strong connection with their villages and were smart about playing the media and politics performed a crucial role, in their view, in saving the villages. But they were also regularly confronted with their weak position; for instance, in the end they had to accept the sale of almost $50 \%$ of the social rental dwellings. 


\subsection{Hallmark of urban renewal}

Urban renewal cannot be put aside, as can sometimes other complex decisions. In that sense the partners are locked into the local network. They can create delays and postpone decisions and even 'sell off their position in the network', but the task remains. Sooner or later something has to be done by a network that is in place. The actors therefore remain dependent on one another; they are forced to buy one another's goods or services, as it were. If they cannot reach agreement at a particular time, it will make sense for them to wait for a more favorable climate, remain alert to what is going on around them and be ready to avail themselves of fresh opportunities when they arise.

Waiting for better opportunities is one of the possible outcomes of interaction in a local network with joint non-hierarchical decision-making. Such an outcome must be seen as a logical consequence of Dutch central government stepping away from hierarchical steering for urban restructuring to allow for steering in local networks. This happened when housing associations got their financial independence in the mid-1990s. The other side of the coin of joint non-hierarchical decision-making in local networks is the possibility of coming up with creative and individual solutions. Achieving creative solutions for complex problems takes time and needs the support of all the members of the network. Doing nothing for a period is not by definition a problem. In fact, it may be a better solution than a hierarchically enforced or weakly supported compromise.

The art of urban renewal in the Netherlands nowadays thus appears to be taking account of the governance processes in the local network of partners. These processes take place anyway. Keeping this in mind increases the likelihood that the collaboration in an urban renewal network will be successful without getting bogged down in deadlocks.

Acknowledgment The authors wish to acknowledge the financial assistance of the Dutch government through the Habiforum Programme Innovative Land Use and of Delft University of Technology through the Delft Centre for Sustainable Urban Areas.

Open Access This article is distributed under the terms of the Creative Commons Attribution Noncommercial License which permits any noncommercial use, distribution, and reproduction in any medium, provided the original author(s) and source are credited.

\section{References}

Aedes vereniging van woningcorporaties. (2007). Antwoord aan de samenleving van de wooncorporaties verenigd in Aedes. Hilversum: Aedes.

Bureau P/A. (1997). Toekomstscenario's voor Tuindorp Oostzaan. Amsterdam, in opdracht van Het Woningbedrijf Amsterdam, Vestiging Noord.

De Bruijn, J. A., \& ten Heuvelhof, E. F. (1991). Sturingsinstrumenten voor de overheid; over complexe netwerken en een tweede generatie sturingsinstrumenten. Leiden: Stenfert Kroese.

De Bruijn, J. A., \& ten Heuvelhof, E. F. (1999). Management in Netwerken. Utrecht: Uitgeverij LEMMA BV.

Elsinga, M., Haffner, M., \& van der Heijden, H. (2008). Threats to the Dutch unitary rental market. European Journal of Housing Policy, 8(1), 21-37.

Haffner, M., \& Elsinga, M. (2006). Dorpspolitiek. Samenwerking renovatie Disteldorp, Tuindorp Oostzaan en Vogeldorp. Gouda: Habiforum.

Klijn, E.-H. (1996). Regels en sturing in netwerken. De invloed van netwerkregels op de herstructurering van naoorlogse wijken. Dissertation, Uitgeverij Eburon B.V., Delft.

Koppenjan, J., \& Klijn, E.-H. (2004). Managing uncertainties in networks. London: Routledge.

Kotler, P. (1980). Marketing management. Englewood Cliffs, New Jersey: Prentice-Hall, Inc. 
Mullins, D., \& Rhodes, M. L. (2007). Special issue on network theory and social housing. Housing Theory and Society, 24(1), 1-13.

Simon, H. (1957). Models of man. Social and rational. New York: Wiley.

Teisman, G. R. (1998). Complexe besluitvorming. Een pluricentrisch perspectief op besluitvorming over ruimtelijke investeringen. The Hague: Elsevier bedrijfsinformatie bv.

Termeer, C. J. A. M., \& Koppenjan, J. F. M. (1997). Managing perceptions in networks. In W. J. M. Kickert, E.-H. Klijn, \& J. F. M. Koppenjan (Eds.), Managing complex networks. Strategies for the public sector. London: SAGE.

Tommel, D. K. J. (1997). Nota Stedelijke vernieuwing, 25 427, No. 1 (letter) and No. 2 (document), House of representatives, 1996-1997 session.

Woningbedrijf Amsterdam. (1996). Tuindorp Oostzaan. Informatiebrochure voor bewoners. Amsterdam: Woningbedrijf Amsterdam. 